\title{
THE CONFLICT OF THE RATIONALITIES: INTERNATIONAL LAW, HUMAN RIGHTS AND THE WAR IN IRAQ
}

\author{
ThOMAS CUSHMAN ${ }^{*}$
}

[When one thinks of international law and human rights, one imagines that they are complimentary phenomena. The goal of international law is to protect human rights, and human rights are to be enjoyed, presumably on a global basis, under the protection of a universally binding rule of international law. To be for human rights is necessarily to be for international law, and vice versa. The central purpose of this essay is to argue that not only is the presumed positive relationship between international law and human rights not necessarily the case, but that the relationship is of a more tense and conflictual nature. In some cases, there is a negative or inverse relationship between law and human rights. While there is an assumption that the promotion of international law and the promotion of human rights are essentially part of the same project of modernity, this is not the case. At a rhetorical level, they appear to be one and the same thing, but at a practical level - literally, at the level at which international law is practiced and at which human rights is practiced - international law and human rights constitute different value-spheres in the contemporary world.]

\footnotetext{
* Wellesley College, USA; Visiting Professor of Law, Birkbeck College, University of London (2005).
} 


\section{INTRODUCTION AND BACKGROUND}

Since the Enlightenment, there have been various modern, liberal, progressive projects aimed at human advancement. One might refer to these as different trajectories of action. One trajectory of action has been the rise of international law, an attempt to render into global form that which has always been present in societies as a source of order, stability, and social control for relations among states. International law is a relatively modern phenomenon, which emerged in the $19^{\text {th }}$ century and which was primarily concerned with regulating the conduct of war, and subsequently the more general conduct of nations, not only among themselves, but of conduct by sovereigns toward their own subjects. Another trajectory of action has been what I call the "cultural project of human rights." This cultural project has consisted of 1. deriving a set of sacred ideals of human existence and the human individual and 2. the attempt to translate these ideals into practice on a global level. It is tempting to think of these trajectories as being virtually indistinguishable, as one in the same. I want to argue that they are not, that they are different trajectories, which only now and then converge, but which are principally divergent and distantiated. This divergence and distantiation has always been evident historically, but has become particularly evident in the period of late modernity. In addition, this divergence is not a result of mutual effect. Rather, it is the case that international law, in critical cultural moments, has come to work against the liberal cultural project of human rights in modernity. ${ }^{1}$ International law, as a formal system of law, and the cultural project of human rights, as a cultural system ${ }^{2}$ are two different modern projects, based on differing cultural logics, which lead to different ways of apprehending the world, different patterns of attention and cognition to worldphenomena, different forms of social action, and differing outcomes for suffering individuals and collectivities in the modern world. It is this conflict and divergence, which has become particularly pronounced in late modernity, that I want to address in this essay, using a case study from recent history - the Iraq war and the conflict about the war - to illustrate it.

\footnotetext{
${ }^{1}$ The longer project upon which this essay is based is an effort to bring the insights of sociological theory and cultural sociology more closely to bear on the subject of human rights, international law, and contemporary political conflicts, especially the war in Iraq: see THOMAS CUSHMAN, A MATTER OF Principle: Humanitarian ARguments For THE WAR In IRAQ (2005); See also Thomas Cushman, The Human Rights Case for the War in Iraq: A Consequentialist View, in HumAn Rights IN AN AGE Of TERROR (Richard Ashby Wilson ed., 2005). On each of these subjects, sociology has done, in my opinion, dismally. While human rights has become something of a global civil religion, there is virtually no sociology of human rights, with a few notable exceptions: see Bryan S. Turner, Outline of a Theory of Human Rights, in 27:3 Sociology 489 (1993). See also ANTHONY WOODWISS, HUMAN Rights (2005). This is in contrast to the fact that the early classical theorists, especially Durkheim and Marx, were intimately involved in discussions of and criticisms of "the rights of man." In addition, while the sociology of law is a highly developed field, there is virtually no sociology of international law to speak of, and this at a time when an entire new class of legal experts in this area and social institutions of global civil society have emerged as the guardians of a new world global order. And, regarding contemporary conflicts, the best that American sociology could do in regard to the war in Iraq was for its main professional association to pass a resolution condemning it, an act which virtually guaranteed that it could not become a serious object of study or theorizing.

${ }^{2}$ Clifford Geertz, Religion as a Cultural System, in The InTERPRETATION Of Cultures, Selected ESSAYS (1975).
} 
The argument presented here is grounded primarily in Max Weber's approach to the sociology of law, in particular, his concepts of formal rationality and substantive rationality. As Trubek points out, "Weber was one of the first scholars to identify a distinctly sociological form of knowledge about the law and to distinguish it from the knowledge of the jurist (or legal scholar) as well as from that of the practicing lawyer." 3 While a sociology of law along these lines is a clear and distinct field, there exists virtually no systematic sociology of international law, Weberian or otherwise. ${ }^{4}$ This is extremely problematic for precisely the reason I argue in this paper: that development of international law is one of the central rationalization processes of modernity (understudied as such by sociologists) and in the current global context is a major form of power, which exerts a strong independent influence on contemporary global politics and social outcomes.

For centuries, the conduct of nations had been regulated by the Roman tradition of law, which emphasized statutes and codes which were considered universal across time and space, without regard to local customs or traditions. In addition, in the pre-modern world, relations between nations were governed by treaties or customary understandings between nations. In principle, nations could make treaties or follow customs with any normative restraint whatsoever: whatever they decided to do was between them and the substance of the treaty or the custom was not held to any external normative or legal standard.

It was only relatively recently that international law emerged in Europe as a new field which sought to define and institutionalize international law as a formal body of law which would regulate the conduct of nations according to specific ethical principles and civilizational values. As Koskenniemi points out, modern international law was essentially a creation of a new class of European legal scholars who wished to establish international law as a real and binding force for global governance, rather than a loose set of theoretical ideas and concepts about how nations should behave. ${ }^{5}$ Prior to that time, theories of international law were primarily

\footnotetext{
${ }^{3}$ David Trubek, Max Weber's Tragic Modernism and the Study of Law in Society, 20 LAW \& Soc'Y REV. 573 (1986).

${ }^{4}$ Weber's sociology of law was, of course, a central aspect of his oeuvre. There is a vigorous body of scholarship which applies Weber's concepts and theories to different kinds of law in different places: see, e.g., Lonn Lanza-Kaduce, Formality, Neutrality, and Goal Rationality: The Legacy of Weber in Analyzing Legal Thought, 73 J. CRIM. L. \& CRIMINOLOGY 533 (1982); Hubert Treiber, Elective Affinities' between Weber's Sociology of Religion and Sociology of Law, 14 THEORY \& SOC. 809 (1985); Martin Albrow, The Application of the Weberian Concept of Rationalization to Contemporary Conditions, in MAX WEBER, RATIONALITY AND MODERNITY 164 (Scott Lash \& Sam Whimster, eds., 1987); Sally Ewing, Formal Justice and the Spirit of Capitalism: Max Weber's Sociology of Law, 21 LAW \& SOC’Y REV. 487 (1987); Stephen M. Feldman, An Interpretation of Max Weber's Theory of International Law: Metaphysics, Economics, and the Iron Cage of Constitutional Law, 16:2 LAW S.I. 205 (1991); David Trubek, Max Weber on Law and the Rise of Capitalism, 3 WIS. L. REV. 720 (1972); David Trubek, Reconstructing Max Weber's Sociology of Law, 37 STAN. L. REV. 919 (1985); David Trubeck, supra note 1; Ronen Shamir, Formal and Substantitive Rationality in American Law: A Weberian Perspective, 2 SOCIAL L. S. 45 (1993). Yet, an autonomous sociology of law, in Weber's sense of a field of inquiry outside of the realm of international jurists proper is virtually non-existent: but see, e.g., Moshe Hirsch, The Sociology of International Law, UNIVERSITY T. L. J. (2005).

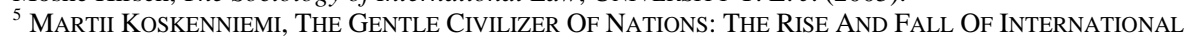
LAW, 1870-1960 (2001).
} 
philosophical treatises, as for example that of Hugo Grotius, whose De jure belli ac pacis $^{6}$ is considered to be the foundational philosophical document of international law. Interestingly, the project of international law, especially in France, was very similar to the social science projects of the $19^{\text {th }}$ century which attempted to derive scientific understandings of the world and uses these as the basis for practical forms of action aimed at ameliorating undesirable social conditions and creating a better world. $^{7}$

The extreme international violence of the first half of the $20^{\text {th }}$ century was testament to the fact that international law existed purely as an abstraction, a fictional set of cultural creations to which powerful states owed no allegiance. Unlike other forms of law, international law had no binding power to back it up, no credible threat of force to compel obedience. Thus, for instance, even though it was normally held to be wrong and illegal for nations to conquer other nations purely for territorial aggrandizement, the Soviet Union and Germany could, in 1939, make a treaty to divide and conquer Poland with virtual impunity. The entire history of World War II was, in a sense, a history of lawlessness. Following the Holocaust, plans for a new world order emerged in the form of the United Nations, which promised a unification of the rule of international law and human rights as the basis for a new global order. At the very basis of this new world order was the United Nations Charter, a code of formal laws and statutes that all member states consented, at least in principle, to be bound by.

What is most important to stress here is that international law was guided by the logic of what Weber called formal rationality. While seemingly driven by ethical considerations, the body of international law which emerged after WWII was an autonomous system (autonomous in the sense of being separate and distinct from nation-states, even while being comprised of them), characterized precisely by its focus on the development of formal procedures, codes, conventions, and statutes which would be binding on nations across time and space, with no concern for particular or local values or differentials in power. From the beginning, it was clear that these new rules for the world were formal constructions rather than concrete norms. At the time of the signing of the UN Charter, the major principals, the United Kingdom, the Soviet Union, the United States, and France were engaged in acts such as empire building which were, according the very letter of the law, illegal. What was important, though, is that these rules became codified as the theoretical basis for how nations should behave, for what they should or should not do and remain, more or less, intact to the present day. Most importantly, the arbiter of what would be legal or illegal was the UN Security Council, and the five nations which comprised its permanent membership.

\footnotetext{
${ }^{6}$ Hugo Grotius, On The Law OF WAR AND PeAce (2004 [1631]).

${ }^{7}$ See KosKenNiEMI, supra note 5. Kosenniemi shows that this was particularly the case in France where international law emerged as an intellectual field which was directly derived from Durkheim's sociology: the object of international law was to discover the social facts about the forms of sociality among nations and to derive international law from these facts.
} 
As Koskenniemi shows, as a result of the Cold War, by the 1960s, the project of establishing a binding rule of international law to which all nations would consent, was essentially finished, replaced by considerations of realpolitik, an emphasis on order and stability (rather than morality), and the dominance of the United States and the Soviet Union. ${ }^{8}$ In spite of international law, for instance, the Soviet Union mounted interventions against Hungary and Czechoslovakia with virtual impunity and was only blocked from the more general occupation of Europe by the treat of US force. China was able to occupy and colonize Tibet, an act which was strictly illegal, but not preventable, since international law, which proscribed such action, had no credible force to enforce the proscription. This has been precisely the central issue for international law: how to restrain the behavior of powerful nations by consent rather than by force, since there is no force which lies behind international law (which raises the question of whether international law is really law or not). The crisis of international law, that which, in a sense, makes it the "victim" is that it is powerless against real power. What I would like to argue is that international law has continued to be ineffectual as a force for the prevention of gross violations of human rights. With all due respect to what international law has suffered at the hands of sovereigns who refuse to consent to its rule, I would also like to explore how international law, as an autonomous system, rather than one completely tied to the caprice of powerful sovereigns, has performed in relation to human rights. ${ }^{9}$

The modern cultural project of human rights emanates from the Enlightenment and found concrete expression in the American Declaration of Independence and the French Declaration of the Rights of Man. These projects were primarily concerned with the specification and sacralization of individual rights over and against state power or the power of individual sovereigns. The early twentieth century brought with it new ideas about social and economic rights, which found expression in the Russian Revolution and later communist revolutions in the $20^{\text {th }}$ century. The real "moment" of the cultural project of human rights, however, was the Universal Declaration of Human Rights in 1946, which specified 50 rights that all individuals were entitled to simply by virtue of being human. The UN Declaration of Human Rights, unlike the UN Charter, was an ideational document, a set of substantive values and ideals rather than a set of laws, rules, and procedures. This is an important point to stress, because it illustrates that from the beginning of the modern project of global governance, there was a tension between the form of international law and the substance of human rights. There was no necessary connection between them and, in some cases, they were in direct conflict.

For example, the UN Declaration of Human Rights guarantees the right of freedom from torture as one of its most important ideals. Yet the UN Charter specifies directly that no country can interfere in the affairs of another state unless it is an act of self-defense. Thus, in a hypothetical situation in which State $X$ is violating the rights of its subjects by systematically torturing them and State Y desires to inter-

\footnotetext{
${ }^{8}$ See KoSKENNIEMI, supra note 5.

${ }^{9}$ It is crucial to see international law as a kind of performance, a perspective which I will raise in the latter sections of this essay.
} 
vene to stop this and promote the human right to be free of torture, it would be illegal under international law for State Y to do so unless it had the consent of the UN Security Council. Yet, the Security Council is guided by a different logic, buttressed not only by the letter of the law, but by the interests of the parties which hold veto power over any declaration of legality or illegality. The Security Council, in this case, is guided by the spirit of formal rationality and pragmatic rationality, by the existence of formal law and the interests of its members. While an intervention may be morally legitimate according to human rights norms, it is, without the imprimatur of the Security Council, illegal. Thus, from the beginning, this new system of global governance was characterized by fundamental cultural contradictions, contradictions which have played themselves historically out in a variety of ways in modern history.

Since the foundation of the United Nations, a massive system of NGOs and activists has emerged which engage in forms of social action which challenge traditional forms of power and domination and aim to assist those who are being abused or in need, those who lie outside the pale and protection of the value-sphere of the culture of human rights. ${ }^{10}$ The cultural project of human rights, at least in its abstract formulation, is a perfect example of a modern project which is based on a system of ethical values and principles, an expression of what Weber referred to as substantive rationality. It is fundamentally an ethical project, a "civilizing process" aimed at the alleviation of human suffering and evil based on a common set of secular (but religiously derived and perhaps even religious themselves) ${ }^{11}$ values and ethical principles which are the bases for various forms of social action. More specifically in Weber's terms, the cultural project of human rights is a form of what Weber calls ethical substantive rationality ${ }^{12}$ based on a common system of ethics and values which are normative templates for individual and collective action in the world.

For Weber, an ethical standard, is "a specific type of value-rational belief among individuals which, as a consequence of this belief, imposes a normative element upon human action that claims the quality of the 'morally good' in the same way that action which claims the status of the 'beautiful' is measured against aesthetic standards." ${ }^{13}$ The resultant forms of social action, are, in Weber's terms, "practicalethical”, and range from small scale projects of individuals or groups who act in the name of these principles to help others to large scale humanitarian interventions by states which aim to rescue or liberate peoples from violence and/or state domination based on some perceived set of values about what is good and evil, right and wrong, just and unjust. In any case, the basis for action is an "ethic of conviction (Gesinnungsethik)." Sociologically speaking, the culture of human rights has become

\footnotetext{
${ }^{10}$ MARGARET E. KECK \& KATHRYN SIKKINK, ACTIVISTS BEYOND BORDERS: ADVOCACY NETWORKS IN INTERNATIONAL POLITICS (1998).

${ }^{11}$ Michael PerRy, The IDEA OF Human Rights: FOUR INQUIRIES (2000).

${ }^{12}$ Max Weber in Stephen Kalberg, Max Weber's Types of Rationality: Corner stones for the Analysis of Rationalization Processes in History, 85 AMERICAN J. S. 1165, 1145 (1980). 
something like a quasi-religion or a global civil religion, as measured strictly along Durkheimian lines. ${ }^{14}$

At this point, those who know little of international law or human rights, but who know Weberian social theory, will immediately recognize the problem: for Weber, formal rationality and substantive rationality are fundamentally antagonistic to one another. ${ }^{15}$ This is a theme which resonates throughout Weber's work, not only in regard to pointing out the tensions between formal rationality and substantive rationality more generally, but with specific reference to the markets and ethics, as well as law and justice. In Economy and Society, in two passages from his brief fragment on the market, Weber notes this tension between the formal rationality of capitalism and the sphere of values. In one passage, he notes: "Where the market is allowed to follow its own autonomous tendencies, its participants do not look toward the persons of each other, but only toward the commodity; there are no obligations of brotherliness or reverence, and none of those spontaneous human relations that are sustained by personal unions.” ${ }_{16}$ In another passage, Weber notes: "The 'free market', that is, the market not bound by ethical norms with its exploitation of constellations of interests and monopoly positions and its dickering, is an abomination (Abscheu) to every system of fraternal ethics. In sharp contrast to all other groups which always presuppose some measure of personal fraternization or even blood kinship, the market is fundamentally alien to any kind of fraternal relationship" ${ }^{17}$ (italics added). This is about as clear a dichotomy as one could draw between formal rationality and substantive rationality: in fact, the strength of formal rationality is not simply seen as being at odds with or in conflict with fraternity, brotherhood, and kinship (which, it should be stressed are central to the ethos of the cultural project of human rights) but as alien to it, an abomination! ${ }^{18}$

This paper transposes Weber's insights on the relationship between the market and ethics to the analysis of the relationship sphere of international law and the culture of human rights. In some senses, the transposition is direct and mechanical, although I will want to tease out some important modifications when discussing the specific ways in which international law and the culture of human rights are in

\footnotetext{
14 Emile Durkheim, The Elementary Forms Of Religious Life ([1915]1965); As Durkheim notes, religion is: "A unified set of beliefs and practices... which unite [into] one single moral community, all those who adhere to them." In this schema, it is human dignity that becomes sacred, while violence, of whatever provenance, against the individual human being is considered profane, to varying degrees. For purposes of this paper, I am content to see the human rights project as a secular project, but nonetheless one which is imbued with a variety of constructions of the sacred and profane. Stephen Kalberg's analysis of this has been extremely valuable for me in considering human rights culture in Weberian terms as a secularized form of the sacred. See, e.g., Kalberg, supra note 12.

${ }^{15}$ See Feldman, supra note 4; See also, Kalberg, supra note 12.

${ }^{16}$ MAX WEBER, ECONOMY AND SOCIETY 636 (1978).

${ }^{17}$ Id. at 637 .

${ }^{18}$ I am unaware of any commentary on Weber's choice of the German word "Abscheu" to describe the relation of the market to ethics. It is a very particular word in German, which conveys a sense of complete and utter disgust - in its adjectival form "Abscheulikeit", it might be best translated as "odiousness". This particular word choice is crucial in pointing out the qualitative essence of the relation between formal and substantive rationality and belies Weber's value judgment of the relations which he purports only to study scientifically.
} 
conflict. But if one substitutes "international law” for "free market”, and "procedure” for "commodity” in Weber's passages quoted above, one will have a pretty good idea of what I want to argue here, to wit: "Where international law is allowed to follow its own autonomous tendencies, its participants do not look toward the persons of each other, but only toward the procedure; there are no obligations of brotherliness or reverence, and none of those spontaneous human relations that are sustained by personal unions.” In a Weberian sense, international law has not only ceased to be a primary instrument of the culture of human rights, but has become a system - perhaps even a regime - of impersonal statutes, procedures, and processes which, in their action consequences, stand against universal ethical principles (or for that matter even particular ones). This is a system which has evolved in the $20^{\text {th }}$ century and which exists in-and-of-itself and in-and-for-itself, and which serves as an instrument through which various actors in the world-system can pursue their self-interests without regard to substantive ethical values. ${ }^{19}$ There is one very important clarification that I want to make here: I do not want to argue that there is no connection between formal international law and substantive principles of human rights. Nor do I want to argue that the formal rationality of international law is not connected to any form of substantive rationality. Nor, do I want to say that international law is an abomination to human rights in all cases. In fact, in terms of the development of responses to gross violation of human rights, international law has done quite well in setting up a new judicial apparatus in the form of the International Criminal Court, which is an institutionalized form of justice aimed at the punishment of violators of international law and human rights. In this respect, it is a significant example of convergence between the rationality of international law and ethical considerations of the culture of human rights, in this case the ideal of bringing to justice and making accountable for their action those who commit crimes against humanity and war crimes accountable for their action. My focus is on the issue of prevention, on those cases in which the formal rationality of international law is often egregiously at odds with the value rationality of human rights which specifies that gross violations of human rights ought to be prevented and not merely punished.

This antagonistic dualism between the formal and the substantive is evident in Weber's thinking about the law as well, even though Weber never really addressed international law in any systematic way. ${ }^{20}$ As Feldman notes, Weber's approach to

\footnotetext{
${ }^{19}$ Michael BARnetT, Eyewitness To Genocide (2002); Michael Barnett (1999) is one of the few international relations theorists to understand law in this sense: his work on the indifference of the UN toward the genocide in Rwanda indicates that the bureaucratic procedures of the UN and international law comprised an autonomous system which made it possible for the organization and international law to completely ignore and fail to prevent the mass murder of 800,000 people in one month in 1994 .

${ }^{20}$ It is an interesting question as to why Weber never examined international law. Well before his own time and during his time, in Germany, as Koskenniemi notes, there was a vigorous debate about the nature of international law in Germany and Weber must surely have been aware of them; see, e.g., KosKENNIEMI, supra note 5. My sense is that Weber sought to understand the more pure forms of law which were really law, according to his own sociological definition of law, which holds that law is only law to the extent that it is backed up by some credible threat of the use of force in case of violations. Indeed, in the history of international law, one of the key debates is not about what law should be, but whether international law really is actually law or not; See, e.g., H.L.A. HART, THE CONCEPT OF LAW
} 
legal history is characterized by a dualism, or a dichotomy between formal law and the normative traditions of various groups. ${ }^{21}$ As with other spheres of life in modern society, various legal spheres becomes increasingly rationalized and come increasingly at odds with and in conflict with systems of substantive values. In Economy and Society, Weber distinguishes between two types of formal law. One type of formal law is that in which "only unambiguous general characteristics of the facts of the case are taken into account" and these can either be facts that are "perceptible as sense data" or facts regarding performances or utterances of symbolic acts. A second type of formal law is law which "definitely fixed legal concepts in the form of highly abstract rules are formulated and applied.” ${ }^{22}$ But he notices that there is a sharp contrast between this formal rationality and substantively rational law. In a system guided by substantive rationality:

The decision of legal problems is influenced by norms different from those obtained through logical generalization of abstract interpretations of meaning. The norms to which substantive rationality accords predominance include ethical imperatives, utilitarian and other expedential rules, and political maxims, all of which diverge from the formalism of the 'external characteristics' variety as well as from that which uses logical abstraction.

International law, throughout the $20^{\text {th }}$ century, has been undergoing a process of rationalization which has increasingly distanced the law from the core substantive ethical and value foundations of the modern cultural project of human rights. It is important to stress here that I am referring to the most fundamental norms of human rights culture, what in legal parlance are referred to as "peremptory norms", which proscribe the most serious violations of ethics. These peremptory norms include such things as genocide, wars of territorial aggrandizement, slavery, genocide, and torture, in short, practices which constitute the extreme negative pole of the binary system of good and evil in the culture of human rights. From the standpoint of international law, these norms are considered to be non-derogable, that is, there are no circumstances in which they are justifiable or allowable.

Yet, in the face of even such strong peremptory norms, these practices remain a constant facet of the modern environment. Just in the last 15 years, genocide has occurred in Bosnia, Rwanda, and is presently occurring in Sudan in the face of full knowledge about what was happening as it was happening; slavery is endemic in the world system with perhaps as many as 27 million people living as slaves; ${ }^{23}$ one out of four nations of the world practice torture in some form as a regular and accepted practice, and this practice is evident even in the so-called "civilized"

(1997); Anthony D’Amato, Is International Law Really Law?, 79 NORTHEASTERN L.R. 1293 (1984/1985). If international law is not really law, then it must be something else, and this is what opens the field completely for sociological considerations of the question: if international law is not law, what it is it? In future work, I will explore international law as performance, rather than power.

${ }^{21}$ See, FELDMAN, supra note 4, at 212.

${ }^{22}$ See, WEBER, supra note 16, at 656-657.

${ }^{23}$ KeVin Bales, Disposable People: NeW Slavery In The Global ECONOMy (2000). 
nations of Europe. ${ }^{24}$ International law has not been the cause of these events, but to a varying extent it has not been able to prevent them and in many cases is indifferent to them. This has much to do with the bureaucratic processes which have been designed to counter them, as organizations such as the UN follow their own bureaucratic procedures and norms. ${ }^{25}$ The increasing rationalization of international law has contributed actively to the carving out of a space in which these practices have become, more or less, obdurate social facts of the contemporary world.

In what follows, I offer an empirical example which illustrates the dramatic tensions between international law and human rights in the modern world. I have chosen to use the case of the war in Iraq, since this a defining moment of the early $21^{\text {st }}$ century and illustrates quite clearly tensions and conflicts between formal and substantive rationality, on the one hand, and between different types of substantive rationality. In addition, by way of looking at the war in Iraq, we can also examine the conflict between the United States and various segments of what might be called "global civil society" united around the idea of peace and formal international law. I want to be very clear that my intention is not to enlist Weber as an ally for my own ideological position on the war. ${ }^{26}$ It is entirely clear that Weber's science does not provide any possibility for the derivation of any kinds of values. Rather, a Weberian analysis focuses on pointing out the conflict of valueorientations, in this case between formal and substantive rationality in the modern world. The analysis here illustrates how the formal mechanisms of international law stand in opposition to the value-sphere of human rights. As I will note later, the only possibility that we, as individuals, have is to choose value positions. As Rogers Brubaker notes, quoting Weber: "Torn between conflicting obligation deriving from different value spheres, the individual must simply choose: [for Weber] 'according to our ultimate standpoint, the one is the devil and the other God, and the individual has to decide which is God for him and which is the devil."’ ${ }^{27}$ If anything, I want to show how a Weberian sociological analysis might offer an unusual and powerful new approach to understanding contemporary conflicts, even if, ultimately individuals are left to their own devices in choosing among mutually irreconcilable value positions.

\section{ThE CONFLICT OF RATIONALITIES AND THE IRAQ WAR}

The general history of Iraq, its particular history under the rule of Saddam Hussein, and the war that was waged against him by an alliance of states, but essentially by the United States and Great Britain are complex matters. In what follows, I would like to draw a rough composite of that history, paying specific attention to some of the central facts of the case, but also to the specific cultural logics which guided

\footnotetext{
${ }^{24}$ Antonio Cassese, Inhuman States: Imprisonment, Detention, And Torture In Europe TODAY (1996).

${ }^{25}$ See, e.g., BARNETT, supra note 19.

${ }^{26}$ See CUSHMAN, supra note 1.

27 Rogers Brubaker, The Limits Of RAtionality: An Essay On The Social And Moral THOUGHT OF MAX WEBER 72 (1984)
} 
various individual and collective action in relation to Iraq and its system of power. As presented here, this can only be but a rather simplified version of events, yet one which is sufficient to illustrate what I mean by the term "the conflict of rationalities." My aim here is to offer a framework which moves beyond the rather facile ideological issue of whether the war was right or wrong, or dramaturgical discussions about Saddam's (or for that matter, the “American Empire's”) “evil”, but sees, instead the war itself and the debates about the war as an empirical case which illustrates the conflict of rationalities in modernity. ${ }^{28}$

In 1958, Iraq became a republic after a coup d'etat against the monarchy of King Faisal II. General Abdul Karim Kassem became the leader of the country and began a program of reversal of the monarchy's previous pro-Western policies. In this sense, Iraq was one of many countries in the world-system which sought dramatically to break away from Western colonial rule in the post-war period. And, as in many of these post-colonial situations, the country became immersed in extreme violence and instability. The country was characterized by a state of civil war and ultimately, in 1968 Ahmad Hasan al-Bakr became the president and brought the Baath Party (which had its origins in Syria) to power. In 1979, Bakr resigned and Saddam Hussein became the president of Iraq. Hussein executed most of his actual and potential political rivals, and became a despot who held power through the use of systematic fear, torture, and genocide. In 1980, he waged a war of aggression against Iran, which lasted for eight years and in which an estimated 1.5 million people were killed. During his reign, Hussein killed an estimated 300,000 of his own subjects.

One of Hussein's primary obstacles to the total domination of Iraq was the Kurdish movement for autonomy. In 1988, the regime of Saddam Hussein waged the Anfal campaign against the Kurds in Northern Iraq, a planned and systematic program of mass murder, torture, deportation, and cultural destruction in which chemical weapons were used. ${ }^{29}$ In 1990, he invaded and occupied the independent country of Kuwait, declared it to be part of Iraq, systematically killed, tortured, and expelled large numbers of the population, and expropriated its substantial wealth for his own personal use. The "world community" (a term which is often used as a synonym for the United Nations, which is many things, but not really a community), recognizing that this was a gross violation of international law against aggressive war for territorial and material aggrandizement, gave its consent for a multinational force to expel Hussein from Kuwait. The war was won very quickly and this force was poised to actually depose Saddam Hussein, but since this was not part of the legal mandate, and because of pressure from local Middle Eastern leaders, the forces retreated and left Saddam Hussein in power, although severely constrained in terms

\footnotetext{
${ }^{28}$ For complete histories of Iraq which are relevant to understanding the nature of totalitarianism in Iraq and the extent of the violence of Saddam's regime: see OFRA BENGIO, SADDAM's WORLD: POLITICAL

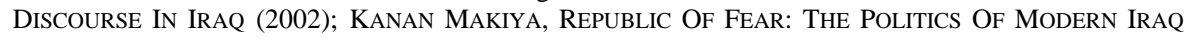
(1998).

${ }^{29}$ For a full report on the Anfal campaign: see Human Rights Watch, Genocide in Iraq: The Anfal Campaign Against the Kurds, available at <http://www.hrw.org/wr2k4/3.htm> (last visited Apr. 2, 2005).
} 
of his exercise of power outside of Iraq and his ability to develop weapons of mass destruction.

A system of surveillance and constraint was put into place to monitor his actions, which instituted international economic sanctions and "no fly zones" within the country itself, aimed at curbing the repetition of genocide in the northern and southern Iraq. But in a formal sense, this system did little to curb his violations of human rights. After the Gulf War in 1991 and throughout the 1990s, the Iraqi regime engaged in an all-out campaign of devastation against the Ma'dan, or Marsh Arabs, Shi'a Muslims who inhabited the marshlands of Southern Iraq. This campaign was characterized by mass executions, widespread imprisonment, torture, and forced migrations; Human Rights Watch estimates that from an original population of 250,000 in 1991, the population of Ma'dan in their ancestral homelands was reduced to 40,000 by 2003. ${ }^{30}$ This certainly constitutes a mass crime against humanity, if not, according to standard sociological definitions, a genocidal campaign. So the fact of the matter is that Saddam Hussein perpetrated at least one genocide and another campaign which was, at the very least, genocidal.

One of the conditions of the victory over Saddam in the Gulf War of 1991 was that Iraq would be subject to weapons inspections. Increasingly, however, throughout the 1990s, the weapons inspection regime deteriorated to the point in 1998 when Saddam Hussein halted all cooperation with weapons inspectors and denied them access to Iraq. During this period, as well, 16 legal resolutions were passed by the United Nations, none of which were complied with by the regime. Increasingly during this time, Saddam Hussein abandoned his secular rhetoric of pan-Arabism and replaced it with Islamist religious rhetoric which called for jihad against the West. In addition, the Iraqi regime offered material support for terrorism, especially to suicide bombers in Israel. In addition, and entirely within the bound of formal international law, Iraq engaged in an "Oil-for-Food" program in which Iraq would be allowed to sell oil in exchange for food, thus, in principle, alleviating the effects of economic sanctions on the Iraqi people themselves. Subsequently, it was discovered that the intention of this legally sanctioned program was compromised by the appropriation of profits by Saddam's regime, as well as the illegal distribution of compensation to various people representing their own personal and corporate interests. By the end of the 1990s and early 2000s, Saddam Hussein's regime was almost completely outside of the rule of international law, perhaps contained by earlier measures, but openly flaunting international law and committing gross violations of human rights. By any measure, and especially by the ethical standards of the UN Declaration of Human Rights, his regime was an aberration to the very core ideas of the cultural project of human rights.

It was against this backdrop that the United States was attacked in September 2001 by suicide bombers from the globalized terrorist network known as al-Qaeda.

\footnotetext{
${ }^{30}$ For a full report on the campaign against the Ma'dan: see Human Rights Watch, The Iraqi Government Assault on the Marsh Arabs (2003), available at

<http://www.hrw.org/backgrounder/mena/marsharabs1.htm> (last visited Apr. 22, 2005).
} 
While Hussein had held al-Qaeda at a distance, there was a clear homology between his own rhetoric and political views and those of al-Qaeda. In this context, and in light of a perceived connection between the ideological and practical aims of alQaeda and Saddam Hussein, in June 2002 the United States declared a new defense strategy of "pre-emptive self-defense", which declared that the US had the right to attack another state if it deemed that state an actual or future threat to US security. Within some bodies of international law (but not within the UN Charter), there are laws which are concerned with regulating what is called "anticipatory self-defense." According to such laws, there are times when war is in the case of the existence of an actual, demonstrable threat. Yet the Bush doctrine of preemptive war went further then this by claiming the right to strike based on conjecture of future threat. Following this declaration, the United States began to press the United Nations to enforce its own legal resolutions against Iraq and to take action against Saddam Hussein, specifically by asking the UN Security Council to vote a resolution to constitute a multi-national force to depose Saddam Hussein. Interestingly enough, this was but a subsequent move from an earlier political act, the unanimous passage of the Iraq Liberation Act by the US Senate in 1998 and the full support of the substance of that act, which included the removal of Saddam from power, by the Democrat American president Bill Clinton and the vice-president Al Gore.

It was at this point that fissures in the response to Saddam Hussein's regime began to emerge and solidify in the global world-system. Several member states of the United Nations, including three members of the Security Council (France, China, and Russia), demanded more time to bring Saddam Hussein into compliance with international legal resolutions. The United States, however, based on past failures to ensure compliance, questioned the legitimacy of the possibility of ensuring compliance and based on its intelligence reports (which later turned out to be faulty), pressed for a resolution to go to war against Iraq and depose Saddam Hussein. This request was resisted by those nations of the Security Council which had the power of veto. Subsequently, a situation emerged in which traditional allies found themselves in conflict, with one party upholding the rule of international law and the other arguing that pragmatic considerations and dangers called for decisive action. A coalition of states was formed, led by the United States and Great Britain, and war commenced in March of 2003. This act was, technically speaking, illegal, since the Security Council did not authorize it. As such, it was considered, according to the letter of the law, to be a violation of the peremptory norm which proscribes acts of aggressive war. The war itself, as a conventional war, was quickly won by coalition forces, but generated resistance among several sectors of the Iraqi population, including former Baathist/Saddam loyalists, and Islamist fundamentalists who were not only indigenous to Iraq, but supported by a more general global coalition of al Qaeda terrorists.

The persistence of Saddam Hussein's regime in violation not only of international law is a prime example which illustrates the conflict between formal and substantive rationality in modernity. From the standpoint of the ethical substantive rationality which is at the core of the human rights project, formal international law and procedure was substantively irrational. We have not yet discussed the idea of 
substantive irrationality, but for Weber, this is a very important concept, since it encapsulates the disjuncture and conflict between different forms of rationality and rationalization processes. The idea of substantive irrationality simply refers to a situation in which formal rationality fails to deliver on the ethics and values of a substantive value sphere. In this case, the substantive irrationality of formal international law is demonstrated simply by the fact that dominance of formal international law within the UN system of global governance stood in direct contradiction to the ethics and values of the UN Declaration of Human Rights. This conflict had been evident throughout the entire history of Saddam Hussein's rule, since formal international law did little to curb his excessive violations of substantive ethical norms. As the crisis in the response to Iraq came to a head in the time leading up to the war, the dependence on the formal rationality of international law intensified and the latter was increasingly distanced from considerations of ethics, or substantive rationality, as a basis for action. In fact, the case illustrates that, to the extent that formal rationality came to dominate as the principle basis for social action, substantive ethical considerations retreated farther and farther from the picture. To put it in more stark sociological terms: the more formal procedures and codes become "sacralized", that is held as the highest universal values within a sphere, the more ethical substantive rationality becomes "de-sacralized".

To understand the idea of substantive rationality, let us construct an ideal-typical actor who considers himself as oriented toward the value-sphere of the culture of human rights. This individual is aware of the norms and values which constitute this sphere, and engages in social action based on his understanding of these norms. According to this individual, the most important norms of the human rights culture are the peremptory norms which proscribe such things as aggressive wars of territorial aggrandizement, genocide, slavery and torture. This individual is also committed to more general values of social and economic rights, which are more positive rights which specify what states ought to do for individuals and collectivities rather than what states ought not to do. In other words, this individual is committed to a form of substantive rationality - his actions are guided by a cultural system of values which are primarily oriented toward helping others achieve freedom, liberty, and a decent life. This individual is aware that all around him there are gross violations of human rights, and, indeed, that a large number of homo sapiens live without even the basic necessities of life, much less enjoy the right to a dignified existence, free of domination and able to pursue their own life-projects. This actor exists within a utopian cultural system of values and ethics. Ideally, he would want to see the sacred ideals of the culture of human rights expanded to as many people as possible. He is, however, aware of the obdurate realities of social existence, of power, economic and social inequality, that is to say, he has a tragic sense of the world. In spite of the rhetoric of advancement and progress, he sees the persistence of human tragedy and recognizes the limitations of the utopian vision by which he lives his life.

In the external environment, he is aware of particular states which have existed quite a long time and which have institutionalized violations of peremptory norms as an essential part of the very fabric of their existence. Indeed, these states are models of the profane, even of evil, by which the substantive positive values of the 
human rights culture are made all the more sacred and meaningful. In some ironic sociological sense, these states are necessary as a reference point for defining the meaning of what is just and unjust, what is good and evil. This individual values the idea of the rule of law and understands that the origins of international law lay precisely in the effort to regulate the "wicked" conduct of nations, to avert war if possible, and, in the event of war to regulate or "civilize" the conduct of war. Guided by these values, this individual needs to make meaning of the situation of Iraq and what should be done in relation to it. As with other "civilized" persons, he looks to international law as a means by which to translate his substantive values into practice. Yet, when he encounters the law, he encounters a set of bureaucratic procedures and legal codes which, it seems, as guides to practical action, have worked more to appease and even intensify gross violations of human rights. For this individual, international law appears to be substantively irrational, seemingly aiding and abetting the very violations of sacred principles which are central frameworks of meaning which guide his social action in the world. The condition of contradiction yields a certain sense of despair, since the only alternative means for reconciling the contradiction and making substantive values once again paramount, are themselves at odds with his fundamental value system. In this case, it is clear that war against Saddam Hussein will be an act of "tyrannicide" and will open the avenues for the Iraqi people to reclaim their popular sovereignty and establish their status as members of the "community of rights" and live according to the "Law of Peoples." ${ }^{11}$ Our individual is in despair, trapped between the Scylla of formal rationality and the Charibdis of the evil of war. The choice of which to yield to is a choice between evils, but nonetheless, in a Weberian sense, a choice which has to be made in consideration of an ethics of conviction.

This hermeneutic experiment simply illustrates how the conflict of formal and substantive rationality might be experienced at the level of subjectivity. What needs to be explained is why international law became, in a sense, sacralized in opposition to considerations of the sacral principles of human rights. It is not sufficient simply to posit that a disjuncture emerged, but to offer some explanation as to why. For Weber, the process of rationalization - whether formal rationalization or substantive rationalization - needs to be seen in relation to specific constellations of interests and historical events which drive the process. I offer here a brief consideration of some of the factors which lead to the "triumph of formal rationality" in the sphere of international law.

\footnotetext{
${ }^{31}$ AlAn GeWIRTH, The COMmUNity Of Rights (1996); Gewirth claims that it is not possible for actors to consider themselves part of a "community of rights" (or what I have been referring to as the cultural project of human rights) while systematically and intentionally excluding others from that community. In this sense, international law as a practice has excluded large numbers of people from the community of rights. In addition, John Rawls, as a neo-Kantian, held that the Society of Peoples would consist of republics of free citizens, not of outlaw states such as Iraq, North Korea, Iran, etc. In each case, law and formal organization stand outside of the core of substantive values; See, e.g., JOHN RAWLS, THE LAW OF Peoples (1999).
} 
As Koskenniemi has shown, ${ }^{32}$ the operation of international law in the post-World War II era was severely constrained by the realities of the Cold War. The guiding logic of that era was realpolitik - states would behave almost purely on pragmatic considerations of their interests and the two dominant states, the United States and the Soviet Union did precisely this. As a result, international law, to the extent that it had any power at all, was reduced to an ideal to which all parties were aware could only yield to raw power and interest. This power did not have the effect of displacing international law as a system of procedures and formal codes, but it did render them increasingly "performative", in the sense that something could be declared legal or illegal, but with little or no result given the fact that the law had no actual power to back it up. Thus, increasingly, international law became a performative practice. Law was something that could be done (in the sense of performed) in light of the fact that nothing could be done.

International law became a formal means which powerless states could at least claim some presence in the global arena, even if such presence conferred no real power and had little effect on specific political outcomes. It allowed for the option of at least displaying some form of counter-hegemony against the realities of power, even if only at the symbolic level. Such displays of counter-hegemony were intensified to the extent that more and more nations participated in them. In the years after World War II, as a result of decolonization, more and more nations became members of the United Nations and, thus brought into the arena of the world community and international law. With this increasing number of nations, specific alliances and blocs emerged in which less powerful nations could pursue their own self-interests and collective interests. International law became, for such alliances and blocs, something which could be instrumentally used to exert some kind of presence on the world arena, and in some cases actual power. More importantly, in becoming strictly a means toward the end of establishing presence, power, and the pursuit of self-interest, international law increasingly became divorced from any system of substantive ethics, since participation in the system of law had nothing to do with the adherence to the substantive norms of human rights. A larger number of new member states of the United Nations after the period of decolonization were what John Rawls referred to as "outlaw" states. That is, they were countries in which gross violations of peremptory norms of human rights were the rule rather than the exception. Nonetheless, membership in the United Nations had nothing whatsoever to do with substantive rationality, or perhaps more aptly put, the substance of sovereignty. The only criterion for membership was to meet the formal criterion of state sovereignty and to be recognized as sovereign by other nation-states. Outlaw states came to be full participants in the system of international law and, more importantly, were enabled in the formation of alliances and blocs against hegemonic powers in which the formal rationality of international law became the primary source of power.

A clear case of this process can be found in the election of Libya in 2003 to be the head of the United Nations Commission on Human Rights, the central organiza-

\footnotetext{
${ }^{32}$ See KoSKENNIEMI, supra note 5.
} 
tional body of the UN which was founded to address gross-violations of human rights in the world. That event was made possible by the alliance of groups of weak states, especially in Africa, which voted for Libya - one of the most egregious violators of human rights in the world-system - to head the commission, while simultaneously expelling the United States from the commission (even though it had been founded by Eleanor Roosevelt and the US had been represented since the commission's foundation). ${ }^{33}$ Here we see a perfect example of the manipulation of formal procedures and rule to the advantage of outlaw states, and, again a disjuncture between formal rationality and substantive rationality. Indeed, the election of Libya to head the commission was an example of the substantive irrationality of formal international law and procedure.

The enduring influence of realpolitik was a force which distantiated formal rationality from substantive rationality. Another factor in this distantiation is what might be called the social control uncertainty. At the most basic sociological level, law is a social form which aims at controlling uncertainty. The post-war period and the emergence of the Cold War was a period of increasing uncertainty, especially with the development of weapons of mass destruction. This was not only an uncertainty about the capricious use of force and the possibility of "mutually assured destruction" through the development of nuclear arms, but the more generalized uncertainty characteristic of the "risk society" ${ }^{34}$ In relation to the exercise of power, international law had always been grounded in a concern for checking the uncertainties and caprices of power. In a condition of heightened uncertainty, international law became an even more important means for dealing with uncertainty. Under the regime of international law, human rights violators such as Saddam Hussein could be checked and contained, but the logic which guides containment has little to do with any consideration of substantive values or ethics. Rather, the logic of containment is purely one of reducing uncertainty through the instrumental means of international law. International law increasingly became tied to a practical logic of containment which assured a certain stability and order, but tolerated gross violations of human rights. As such, formal international law aimed at containment is substantively irrational from the point of view of the values of human rights culture.

One of the principal arguments against the Iraq war is that it would lead to chaos at a number of levels in the world-system. So the argument went, in the Middle East, it would upset the containment of the passions and problems in that area and actually exacerbate the problem of terrorism by creating more ressentiment and lead to the expansion of the ranks of terrorists. At the global level, the unilateral action of powerful states against international law, especially if grounded in substantive rationality of humanitarianism, freedom, and liberation, would send the signal to other powerful states that they, too, could act outside of international law. This would produce a global situation of capricious use of power, "bogus" humanitarian

\footnotetext{
${ }^{33}$ To give a quantitative sense of the strength of this vote: on the committee, 33 members voted for Libya, 3 against, and 17 abstained, in this case, abstention being essentially a deferral to the majority. ${ }^{34}$ ULRICH BECK, RISK SOCIETY: TOWARDS A NEW MODERNITY (1992).
} 
wars, and intensify the condition of generalized uncertainty. Such a view served to strengthen the movement toward the formal rationality of international law, even if, as I noted above, this adherence to the law was not an actual form of power, but a kind of performative ritual. In this sense, following in the classical traditions of sociological and anthropological thought on ritual, we might posit that the more actors perceive a situation of risk and uncertainty, the more they are driven to ritual forms which provide certainty and order. In this case, the war in Iraq opened up a Pandora's Box of uncertainties which enhanced the attractiveness of the formal rationality of international law, if not as a real form of power, at least as a performance of certainty and order.

A final explanation lies in a consideration of the rise of a class of legal experts in the post-war world-system. As we noted earlier, international law in the $19^{\text {th }}$ century was a creation of a new class of legal experts. The development of international law occurred concurrently with the rise of the profession of the international lawyer. ${ }^{35}$ This new professional class, and the law it attempted to create was not, however, disinterested. By its very aim of attempting to regulate the conduct of states, the laws of war, and other forms of power, international law and the international legal system set itself up as an autonomous system of power and the elites who comprised it a new class of political elites. While quite literally extirpated by the events of the first half of the twentieth century, international law and a new class of international legal experts emerged like a phoenix from the ashes of World War II. This new class of experts has only intensified since the war, joined by a whole new class of global activists from non-governmental organizations who, as a bloc, represent a formidable source of power against sovereign states. The cultural capital of this new class is international law and it is extremely important to understand the power, interests, and culture of this new class as a force which has intensified the formal rationality of international law. This is a class characterized by its own cultural norms and what Alvin Gouldner referred to as a "culture of critical discourse.” ${ }^{36}$ Even if we disregard the attraction of weak states to international law as a form of empowerment, or the strengthening of international law as a response to uncertainty, we must also consider that this new system of elites, which consists primarily of legal experts, has a vested interest in maintaining its own autonomy and power, as a class-for-itself in Marx's terms, in the world system. If the system of international law is threatened by powerful states or unilateral decisions to go to war, then so too is the class of experts for whom international law is the basis of its power.

What I have outlined above are three possible explanations for intensification of the rationalization of international law. In this case, one can even speak of a "sacralization" of international law, since expressions of law were not only instrumental and rational, but performances of the sacred ideals of order, stability, and empowerment of the weak. This is a topic which needs further development, since it is clear that Weber's perspective on rationality seemed to pit formal rationality and instrumental

\footnotetext{
${ }^{35}$ See KOSKENNIEMI, supra note 5.

${ }^{36}$ Alan Gouldner, The Future Of InTEllectuals And The Rise Of The New Class (1982).
} 
reason against substantive value-spheres, each of which had its own pattern of values, ethics, and a sense of the sacred.

These explanations are by no means exhaustive, but indicate that the rationalization of international law is driven, at least, by concrete historical events, the interests of states, and the interests of new classes of experts and activists. In any case, from the strict standpoint of the substantive cultural project of human rights, it is this rationalization process which is the source of substantive irrationality. In what follows, I turn to examine another form of the conflict of rationalities: the conflict of substantive rationalities.

\section{The Conflict of Substantive Rationalities in GLOBAL CIVIL SOCIETY}

The Iraq war was not only unpopular to a large number of states in the world system. The war was also extremely unpopular at the grassroots level of what might be called global civil society. Well before the war began, large-scale demonstrations against the war occurred all over the world, especially in European and American cities. These demonstrations were usually referred to as "peace demonstrations", an important nomenclature because it indicates that, as collective actions, these events were, sociologically speaking, expressions of a substantive rationality which defined peace as an ultimate value and, conversely, war and American hegemony/power as an evil. As empirical manifestations, these forms of collective behavior indicate the existence within the more general society of what might be called "peace culture" (or, alternatively, "anti-war culture”). It is tempting to assume that peace culture is synonymous with human rights culture, but as I shall soon discuss, this is not necessarily the case.

In almost no case - even though many if not most of the demonstrators probably would have considered themselves to be part of the global culture of human rights did any of the demonstrations refer to the gross violations of human rights, or the suffering of the Iraqi people under Saddam Hussein's regime. This suffering had been rather well-documented, and more importantly, most of the Iraqi population had expressed the public opinion that they desired intervention as a means of liberation from Saddam's regime. ${ }^{37}$ The human rights violations of Saddam Hussein and the suffering of the Iraqi people were not a central part of what I would call the structure of attention of global civil society toward the war. Indeed, in stark contrast, these collective displays were primarily symbolic attacks against the United States, collective spectacles in which the United States, in general, and the American president were quite literally, to use Jeffrey Alexander's expression “engorged” with evil. ${ }^{38}$ The American president, for his part, had already engaged in this same kind of symbolic project by presenting a social construction of evil in which he

\footnotetext{
${ }^{37}$ See CUSHMAN, supra note 1.

${ }^{38}$ JefFrey AleXANDER, The MeAnings Of Social LifE: A Cultural SoCiOlogy (2003).
} 
referred to Iraq, Iran, and North Korea as "the Axis of Evil.” These nations became the principal "receptacles" of evil, and when "filled", were appropriate targets for preemptive military action. The United States, for opponents of the war, was a principal receptacle of evil, and when "filled", became an appropriate target for collective social action against it by either individuals, collectivities, or states.

I make this point to illustrate that much of the conflict about the war took place at this symbolic level of meaning-making within two differing substantive value orientations. As such, what I have referred to as the conflict of rationalities was not limited to the conflict between the formal rationality of international law and the substantive rationality of either human rights or the substantive rationality of the American values and ideologies, but between different forms of substantive rationality. What is most interesting from a sociological point of view is that there was virtually no mobilization of global civil society on behalf of the Iraqi people, who, at least according to the usually expressed values of the cultural project of human rights, would have been (and actually were, prior to the war) the direct subject of attention on the part of human rights activists. For instance, the organization $\mathrm{Hu}-$ man Rights Watch, one of the largest non-governmental organizations within the human rights culture, had devoted decades to providing detailed analyses of human rights violations in Iraq. Human Rights Watch had always maintained certain political neutrality in political affairs, so as to enhance its reputation and status as an "equal opportunity" exposer of human rights violations. But in this case, in contrast to its usual position of neutrality, it actually took a position against the war as a humanitarian effort, based on its view that the motives of the war were not humanitarian, and ignoring any consideration of the consequences for the Iraqi people. $^{39}$

Here, a crucial sociological question emerges: why was it the case that the structure of attention to the war followed along the lines of a substantive rationality which focused on the value of peace, the evil of war, and the danger/evil of the United States, rather than a substantive rationality which valued solidarity with the Iraqis and the evil of fascism and totalitarianism? It is possible to imagine a scenario in which the Iraqi people appealed to Western global civil society and that crucial sectors of that civil society could be mobilized to support their efforts to be liberated. This was, in a sense, the model of the Spanish Civil War, in which most members of the liberal community outside of Spain supported the resistance to Franco. And it is clearly the case, as Jeffrey Alexander has argued, that the civil rights movement in the United States was catalyzed by the mobilization of Northern elites to the cause of redressing injustice in the South. In this case, the community of liberals in the West who mobilized in support of the war, not on the grounds in which George Bush attempted to legitimate it, but on the grounds of some fundamental commitment to anti-fascism, freedom, liberation, and solidarity with the

\footnotetext{
${ }^{39}$ I have provided an extended critique of HRW's position, as well as an argument which considers solidarity with the Iraqi people and the positive consequences of the war for human rights in Iraq; See CUSHMAN, supra note 1.
} 
Iraqi people was decidedly small, so small, in fact, that it constituted a tiny majority of the worldwide liberal community.

Why was this the case? The sociological answer to this question has to move beyond some facile explanation that many people in the global civil society found George Bush to be extremely distasteful. ${ }^{40}$ I would suggest some preliminary answers here. Perhaps the simplest explanation is that, for the most part, global civil society, as a "society of liberals" has come to define the absence of war as a higher value than the protection and rescue of those whose human rights are being devalued. That is to say, while the values of human rights remain accessible and viable as keys which might be played in a performance of liberal identity, they remain primarily performative values available for the "public display of the right attitude." Who among liberals, for instance, is against human rights? The culture of human rights is always available for the performance of liberal identity. As performances, in J.L. Austin's sense, one can say one is for human rights and assume by so saying that one has done something. ${ }^{41}$ But from a practical point of view, saying something may not have anything to do with doing something and, in some cases, may become a stand-in for doing something. Performances are themselves structured and conditioned by the social contours in which they exist: increasing social differentiation and social distantiation from others characteristic of modernity means that saying something may be the only option for actors who want to "make a difference" but cannot. In addition, such performative declarations of being "for" human rights, might be as much about creating an identity for the self as it is in any meaningful way a means of doing something for the Other.

There are powerful historical reasons why peace and stability have become the cornerstones of the substantive rationality of global civil society. In the European case, there is a certain war-weariness, well-grounded in the historical experiences of war in $20^{\text {th }}$ century Europe. ${ }^{42}$ In the American case, the Iraq war was reminiscent of the Vietnam war, which had become well-sacralized as an evil historical event on the American left, and even among the more general population. As such, any possibility of war was bound to be symbolically circumscribed by the collective memory of the evil of war, which itself has become a crucial aspect of not only realpolitik ideologies of containment, but of the very meaning system of the culture of global civil society.

Another reason has to do with what might be called the "ideological mismanagement" of the war by American political elites. It would be foolish to address the question I raised above purely by resorting to extraneous explanatory factors. In its

\footnotetext{
${ }^{40}$ I would add here one ethnographic observation relevant to the interpretation of the war in Iraq: one of the primary hurdles to sociological understanding of the war and the response to it has been, when it is raised as a subject of intellectual and scholarly study, there is almost always a hasty retreat on the part of intellectuals and scholars who opposed the war into a reactionary, reductionistic and ideological morass which is distinctly anti-sociological, if not more generally anti-intellectual. This is a subject that deserves far more consideration than I can offer here.

${ }^{41}$ J.L. AUSTIN, HOW TO DO THINGS WITH WORDS (1962).

${ }^{42}$ OMEr BARTOV, MirRors Of DESTRUCTION: WAR, GENOCIDE, AND MODERn IDENTITY (2000).
} 
initial incarnation, the legitimacy of the war was grounded almost exclusively in the practical rhetoric of self-defense: Saddam Hussein had violated all of the resolutions which were made to enhance security, and intelligence showed that he was a threat. Of course, this turned out to be a claim that was not substantiated, at least to the degree to which the US had made it. At best, what could be proved was that Saddam Hussein had more or less disarmed according to the terms of the initial resolutions, but that he had left an infrastructure in place that, with the financial aid from the Oil-for-Food program, the degeneration of the inspection process, and the bureaucratic torpor and indifference of the UN could be reconstituted.

As it became clear that the central justification for the war - weapons of mass destruction were not present in appreciable quantities - the American political elite slowly and gradually began to deploy the rhetoric of liberation, freedom, democracy, and human rights. Since the credibility of the more pragmatic rationale for war had been comprised, so too were any subsequent rationales for the war, even those that would have normatively resonated with liberal members of the human rights culture. This was the case even though this rhetoric actually resonated with the desires of the Iraqi people for such liberation, freedom, or human rights (and almost all survey research subsequent to the war shows these values to be strongly evident among the Iraqi population). ${ }^{43}$ The response to this shift in rhetoric was one of decided cynicism or what Peter Sloterdijk has referred to as "cynical reason." ${ }^{44}$ Cynical reason perhaps might be another form of rationality in modernity, one which Weber may have been trying to capture in his metaphors of disenchantment (but which his friend Georg Simmel really did capture in just a few short passages from The Philosophy of Money). ${ }^{45}$ Cynical rationality seems to be distinct from either formal or substantive rationality: it does not emphasize form or substance, but independently calls for the discreditation and devaluation of both form and substance. $^{46}$ This type of reason subjects any and all statements, especially by political elites, to the hermeneutics of suspicion, with the result that even the most resonant of moral rationales, especially if contaminated by other factors, is doubted and discounted as a source of legitimation. Since most of the criticism of the war came from the global left, it is reasonable to surmise that some of the diagnoses of the cultural crises of the left by such thinkers as Richard Rorty or Todd Gitlin concerning the lack of commitment to global values and common dreams is also evident at a more global level. ${ }^{47}$ Further explorations of this issue might be explored as part of what might be called "sociology of indifference", indifference

\footnotetext{
${ }^{43}$ See CUSHMAN, supra note 1.

${ }^{44}$ Peter SloterdiJK, CritiQue Of Cynical Reason (1987).

${ }^{45}$ GeORG SiMmel, The PHILOSOPHY OF MONEY (1990).

${ }^{46}$ This line of thought is suggested in several important works which define cynicism as a central aspect of modernity; See, e.g., JefFrey C. GOlDFARB, ThE CyNiCAL SOCIETy: The Culture Of POLITICS AND the Politics of Culture In AMERICAN Life (1991); RiCHARD STIVERS, THE CUlture Of CyNiCiSM: AMERICAN MORALITY IN DECLINE (1994); Timothy BlEWES, CYNICISM AND POSTMODERNiTy (VERSO, 1997).

${ }^{47}$ RiCHARD RoRTy, ACHIEving OUR COUnTRY: LEFTIST THOUGHT IN TWENTIETH CENTURY AMERICA (1998).
} 
being, in my opinion, one of the crucial understudied phenomena in the $20^{\text {th }}$ century. ${ }^{48}$

As with our discussion of formal rationality above, these explanations of the dominance of the substantive rationality of what might be called "peace culture" or "anti-war culture" within global civil society by no means are exhaustive. What is called for is a more general sociological account of this form of substantive rationality as a central constitutive value-orientation of global civil society and, more importantly, how it is that "peace culture" and "human rights culture" might actually be in conflict rather than part of the same cultural project of global civil society.

This statement might be puzzling to those who consider that a commitment to peace and a commitment to human rights and social justice are not as incompatible as I have made them out to be. The last few years have witnessed the rise of movements which characterize their aims as the establishment of "Peace and Justice". Indeed, such movements have even spilled over into academic curricula in the form of "peace and justice" programs of academic study. In a general sense, these terms are considered intuitively to be coterminous. Yet, as social phenomena, peace and justice may not necessarily be related at all, and in fact, may be in opposition in many cases. For example, Emperor Hirohito was almost certainly guilty of war crimes during World War II, but in the interests of peace and stability was allowed to remain as emperor. The absence of war in Iraq would surely constitute a state of peace, although it would maintain a totalitarian system of violence and an unjust society in Iraq. As Kalberg notes, "Substantively rational points of view may differ within a single sphere." ${ }^{49}$ I would argue that this is the case within the value-sphere of global civil society, even if "peace culture" is more strongly dominant at the present time. And it is the case that the substantive rationality of "peace culture" is much more "rational" from the standpoint of the formal system of international law, since international law formally aims to establish stability and regulate war. International law and peace culture form a "coalition in a triad", ${ }^{50}$ where the third party which argues for wars grounded in the value of the advancement of human rights is seen as extremely substantively irrational. This coalition also views new American values and ideologies of salvation and the new "American messianism" as substantively irrational. Yet from the standpoint of the third party, the formal rationality of international law is substantively irrational and the substantive rationality of peace culture is irrational because it ignores gross violations of human rights and aligns itself with a system of formal law which is, in Weber's terms, an "abomination to all systems of fraternal ethics.”

\footnotetext{
${ }^{48}$ See SiMmEL, supra note 46. The basis for such sociology was laid out very clearly in Georg Simmel's discussion of cynicism and the blasé attitude.

${ }^{49}$ See KALBERG, supra note 12.

${ }^{50}$ THEODORE CAPLOW, TWO AgAinst ONE: COALITION I TRIADS (1968).
} 
Following Weber it is important to stress that the radical perspectivalism of any discussion of conflicting rationalities. ${ }^{51}$ What is rational from one point, is irrational from the other standpoint and vice versa. As Kalberg notes, "Life-spheres... defend their own value postulates as 'rational' and label those of other life-spheres as 'irrational'." ${ }^{2}$ There is no possibility that a proper form of rationality can be derived from sociology. All positions are equally valid on their own terms, and it is impossible to prove which one of them is "right" in any ethical sense, so we find ourselves, as Weber, not only recognizing the obdurate reality of rationalities in relation to one another and in concordance and conflict with one another, but we also find ourselves locked within that reality, that is, the end result of our analysis produces a certain sense of despair.

\section{The Contemporary Condition of LiBeral Despair}

In this essay, I have tried to illustrate, using the case of the Iraq war, that the conflict of rationalities that Weber first outlined in his own work persists into the $21^{\text {st }}$ century. I have argued that the formal rationality of international law is increasingly at odds with the substantive rationality of the cultural project of human rights. In addition, I have argued that within the larger culture of global civil society, there also exists a conflict of substantive rationalities. The major fault line of this conflict lies in the struggle between peace culture/anti-war culture, on the one hand, and human rights culture, on the other. I have suggested some preliminary explanations for the process of the formal rationalization of the law, as well as the substantive rationalization of global civil society and have suggested that Max Weber's theories of rationalization processes and types of rationality remain valuable conceptual and heuristic devices for understanding contemporary social, political, and cultural conflicts.

Yet, what is the use of translating a set of empirical particulars about a present-day conflict into a theoretical schema which merely conceptualizes these conflicts? Of what use is such knowledge, especially if it only converts actually existing historical fault lines into theoretical ones? The scenario I have presented seems explicitly pessimistic in Weber's own sense that in understanding the conflict of rationalities we have not in any way laid out a path of escape from or reconciliation of this conflict. David Trubek has described Weber's philosophy of history, derived from his sociological analysis of modernity, as a form of "tragic modernism". ${ }^{33}$ Jeffrey Alexander has described Weber as a "liberal in despair." 54 There is plenty of evidence that the conflict of rationalities has led to the emergence of despair, or perhaps disenchantment within global civil society. International lawyers despair over the ineffectuality of their formal international law in the face of American hegem-

\footnotetext{
${ }^{51}$ See also KALBERG, supra note 12.

${ }^{52}$ Id.

53 See TRUBEK, supra note 4

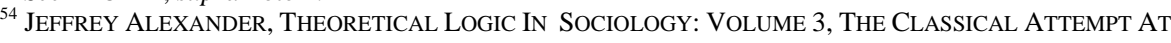
THEORETICAL SYNTHESIS: MAX WEBER (1983).
} 
ony. Peace activists despair over the war in Iraq and the idea that war might be an appropriate means for overthrowing tyranny and establishing a regime of human rights. Human rights activists despair over the persistence of human rights violations in the world and the obdurate persistence of phenomena which violate the very ethical core of their value-sphere and they despair when international law becomes a mechanism of domination rather than liberation. Indeed, it might be appropriate now to engage in the ethnography of despair, in order to capture the elementary forms of disenchantment and despair that are a product of the conflict of rationalities. $^{55}$

In Weber's philosophy, all talk of reform seems senseless, since there can be no agreement or concordance among the various forms of rationality. Almost surely, Weber would see the United Nations and international law as "an iron cage", perhaps even a form of bureaucratic despotism. As Langenbacher has noted, "[for Weber], bureaucratic despotism will have an all-powerful, insulated plutocratic ruling class, differing from previous despotisms by being substantially more resilient and ineradicable." ${ }^{56}$ Yet Weber, the theorist of power, would also see the perils and pitfalls of an unrestrained use of military power and the doctrine of pre-emptive war. And he would most likely see attempts at building global cultures of value as the basis for international relations and the relationships among human beings as being not only utopian, but impossible in the face of the mutual irreconcilability between formal and substantive rationality, on the one hand, and various substantive rationalities on the other. In the face of these realities, despair borne of sociological understanding seems to lead only to indifference and inertia. Is this the future?

As I mentioned earlier, Weber informed us that, ultimately each individual has to choose which type of rationality is God and which is the devil. There may be no possibility of reconciliation of the rationalities. Perhaps the only possibility might be for a dialogue among the rationalities, yet such a dialogue is itself limited by the fact that rationalities are the very source of meaning and action in the world, and as such mutually impenetrable. Weber's own involvement in politics and his specification that in light of the conflict of rationalities we must choose our own ethnic of conviction might be the best we can do. In some senses, Weber anticipated the postmodern view that, in the failure of grand narratives and the triumph of instrumental reason, freedom consists in the development of a virtual infinity of "lifeprojects" in which individuals decide on their own courses of action based on their own derivations of what is meaningful to them. Whether such life projects can coexist in plurality or lead to new forms of individual and collective conflict remains to be seen.

\footnotetext{
${ }^{55}$ Along those lines, I would suggest beginning with that category of liberals who have despaired at the re-election of George Bush and are said to be suffering from "Post-Election Selection Trauma” (PEST), a category of mental illness recently specified by the American Health Association.

${ }^{56}$ Eric Langenbacher, Disenchanted Liberals: Alexis De Toqueville and Max Weber, 1 INTERNATIONAL J. P. E. 27 (2001).
} 